\title{
Legal aspects of quarry recultivation using the municipal solid waste
}

\author{
Svetlana Byvaltseva* \\ Ural State Mining University, 620144, Kuibyshev st., 30, Yekaterinburg, Russia
}

\begin{abstract}
The article is devoted to the study of legal issues of the quarry recultivation using the municipal solid waste. In recent years, insufficient attention has been paid to this problem in the scientific literature that is related to the statutory ban on the quarry recultivation with the municipal solid waste, introduced in 2014. Meanwhile, the problem of increasing the areas disturbed by both the resource development and the waste disposal is becoming truly catastrophic. In order to determine the legal possibility of solving this issue, the study was performed in relation the legal aspects of the quarry recultivation and the municipal solid waste disposal. Based on the study, the author concludes that the solution to this problem is possible in two planes - by changing the applicable legislation or by implementing the quarry recultivation using the waste in two stages in accordance with the applicable legislation.
\end{abstract}

\section{Introduction}

Despite the importance of legal regulation of the quarry recultivation using the waste, insufficient attention is paid to this issue in the scientific literature. Thus, the majority of publications devoted to the issues of quarry recultivation using the solid household waste date back to 2014 and earlier $[1,2]$. The fact is that the Federal Law No.458-FZ dated December 29, 2014 introduced clause 10 in Article 12 of the Federal Law No.89-FZ dated June 24, 1998 "On Production and Consumption Wastes". According to this clause, the use of municipal solid waste (MSW) for the quarry recultivation is prohibited.

Meanwhile, this issue accumulates two significant environmental problems. One of the urgent environmental problems for the Russian Federation is the environmental destruction during the mineral deposit exploitation [3]. It is noted, in particular, that in those areas where the mining industry is developed, the scale of man-made newly formed structures resulting from the resource development is so large that it can be argued that they replace the natural ecosystems [4]. In this regard, the severity of the quarry recultivation issue in the foreseeable future will only be intensified.

Another global problem of modern times is the catastrophic increase in the area occupied by both the industrial and municipal solid waste [5]; the situation in the field of solid household (municipal) waste management leads to the dangerous environmental

\footnotetext{
${ }^{*}$ Corresponding author: russianeng@mail.ru
} 
pollution [6]. Therefore, the issue of the solid municipal waste disposal is more relevant than ever.

In view of this, the objectives of this paper are to study the current scientific positions, applicable legislation, and world practice on the aspects related to the quarry recultivation and waste emplacement, in order to solve the issue of the possible quarry recultivation using the MSW and to develop legal recommendations for the issue under consideration.

\section{Research design}

The present study was conducted on the basis of standards and empirical material, using the special legal cognition methods, in particular, the method of comparative law, the systemanalysis method for the legal standards, the formal legal method to determine the main aspects of quarry recultivation and waste emplacement.

For a theoretical interpretation of the studied legal positions, the logical methods were used, such as deduction and generalization to develop the legal recommendations on the issue of quarry recultivation using the MSW.

\section{Results and discussion}

According to the study results, we can conclude that the problem of disturbed lands is quite acute in Russia.

Thus, the total area of disturbed lands in the Russian Federation in 2017 amounted to 22,051 hectares, among which 16,065 hectares were disturbed during the mineral deposit exploitation; the area of disturbed lands during waste emplacement amounted to 1,201 hectares [7].

Changes in the natural landscape that are inevitable in the case of any mineral extraction method, reach the catastrophic proportions when applying the open-cut mining. During the open-cut mining works, about $60-85 \%$ of lands are disturbed [8] that cannot but have a significant negative impact on the environment.

For a more detailed study of the issue under consideration, it is necessary to refer to the applicable legislation. Clause 10, Article 12 of the Federal Law No. 89-Ф3 that regulates waste management, prohibits the MSW use for the quarry recultivation.

The law under consideration outlines the production and consumption waste and the MSW. The production and consumption wastes are substances or objects that are formed during the production process or during the consumption process. It can be noted that the modern definition of waste has adopted the definition provided by the Basel Convention on the Control of Transboundary Movements of Hazardous Wastes and their Disposal (concluded in Basel on March 22, 1989, ratified by the Russian Federation on November 25, 1994).

The municipal solid waste is defined by the Federal Law No. 89-FZ as the waste that is generated during the process of consumption by individuals in the residential buildings in order to satisfy personal and domestic needs. The law also includes the waste similar in composition to the waste generated in the residential premises that is obtained as a result of the activities of individual entrepreneurs and legal entities. Thus, the concept of municipal solid waste is included in the concept of production and consumption waste. Accordingly, the quarry recultivation with the production and consumption wastes is possible only for those types of waste that are not municipal solid wastes.

To be specific, it should be noted that the term "household waste" is also used in some legal instruments. An explanation of this issue is contained in the Integrated Strategy for the Management of Municipal Solid (Household) Wastes in the Russian Federation 
(approved by the Order of the Ministry of Natural Resources and Environment of Russia No.298 dated August 14, 2013). This strategy suggests to treat the municipal solid (household) waste as the waste that is generated as a result of consumption of goods by the citizens in the apartment buildings and residential buildings and included in the consumption waste. On that basis, these concepts should be considered as synonyms.

While defining the municipal solid waste as the consumption waste, he Federal Law No. 89-FZ simultaneously does not disclose the concept of production waste, and does not establish restrictions on the quarry recultivation using such waste. On the basis of which it can be concluded that the law-making body in principle does not exclude the possible use of waste for the remediation purposes.

In order to determine the possibility of abandoned quarry recultivation by emplacement of the municipal solid waste, it is necessary to determine the relations between the concepts of "reclamation" and "emplacement".

The concept of "land reclamation" is determined by the Decree of the Government of the Russian Federation No.800 dated July 10, 2018 (as amended on March 7, 2019) "On the implementation of land restoration and conservation". Following the Land Code of the Russian Federation (part 5, Article 13 of the Land Code of the Russian Federation), the decree includes the measures of land-oriented recreation and its degradation prevention in the concept of reclamation. As a result of reclamation, the lands must be brought into a state in which they will be suitable for their intended purpose and in accordance with the permitted use. In the case of quarry recultivation related to the industrial lands, its reclamation for intended purpose raises certain questions, since the use of lands without the extracted minerals is not always possible for industrial purposes. It is confirmed by international experience that will be discussed below.

The definition given in the void Order of the Ministry of Natural Resources and Environment of the Russian Federation No. 525 and the Committee of the Russian Federation on Land Resources and Land Management No. 67 dated December 22, 1995 "On Approving the Basic Provisions on Land Reclamation, Removal, Preservation and Sustainable Use of the Fertile Soil Layer" is more appropriate in this sense. In accordance with this definition, it was proposed to understand the land reclamation as a set of works aimed at restoring the efficiency and economic value of disturbed lands, as well as improving the environmental conditions. This definition is more capacious and allows the use of a larger number of options for the disturbed land restoration, since the applicable definition allows the land reclamation only to the state in which it can be used for its intended purpose that was determined prior to reclamation. It significantly limits the possibilities for its reclamation.

This is also confirmed by other provisions of the Decree of the Government of the Russian Federation No.800 dated July 10, 2018 (as amended on March 7, 2019) "On the implementation of land restoration and conservation", in accordance with which the disagreement of the persons specified in paragraph 15 of the Rules (approved by this decree) with the proposed changes in the intended purpose and permitted use of lands after its restoration, is the basis for refusal to coordinate the land restoration project (subsection "e", clause 19 of the Rules).

The order of the Ministry of Natural Resources and Environment of the Russian Federation No.525, order of the Committee of the Russian Federation on Land Resources and Land Management No.67 dated December 22, 1995 allowed the possible changes in the intended purpose of the reclaimed area using the wording "restoration purpose". It was suggested to understand such restoration purpose as the disturbed land restoration for a specific intended use [9]; the disturbed land reclamation could be performed for its restoration for the agricultural, forestry, water management, construction, recreational, 
environmental and sanitary-improving purposes that seems more successful for the reclamation purposes.

The definition given by the Decree of the Government of the Russian Federation No.800 dated July 10, 2018 proposes the land reclamation options. Its list is not exhaustive, as indicated by the wording "including" used during listing of these methods. The advantage in the reclamation definition given by the Decree of the Government of the Russian Federation No.800 dated July 10, 2018 is the inclusion of measures to prevent land degradation.

In the world practice, various options for the quarry recultivation are used, such as the secondary use of mining as a dump, museum, sports facility; the transformation of lands disturbed during the open-cut mining into the shallow forest lands [10]; the use of quarries for the storage of overburden grounds and cleaning rejects, waste of the mining industry and other industrial production; provision of reservoirs [11, 12, 13, 14]. During the reclamation process, there is also the issue of sustainable use of the developed spaces.

The use of waste (including the municipal solid waste) for the quarry recultivation undoubtedly contributes to the solution of this problem and is an option for the beneficial use of waste due to the vast areas of both waste emplacement and quarries. In addition, due to its natural physical properties, the quarry requires a smaller amount of work to be performed as a waste landfill site. Another advantage is that when the waste is emplaced in the quarry, a simultaneous restoration of the disturbed landscape is performed [15]. It is typical that until 2014, the quarries in Russia were used to emplace all types of waste. Obviously, the relevant ban on the quarry recultivation with the MSW was introduced by the law-making body due to the fact that the quarry filling with the unprocessed waste leads to the fact that it becomes an environmentally hazardous object. It makes it impossible to comply with the requirements established by part 1, Article 51 of the Federal Law "On Environmental Protection" in relation to the collection, accumulation, disposal, storage and burial of the production and consumption waste in the conditions and by the ways that are safe for the environment.

We can see similar provisions in the Basel Convention that requires ensuring that the environment and human health are not affected during the waste disposal.

According to paragraph 2 of the national standard of the Russian Federation "GOST R 536912009. Resource saving. Waste management. Certificate for the 1-4th hazardous class waste. Basic requirements", the waste disposal is performed by the disposal of inert components (parts) and/or removal of the components hazardous for the environment.

The experience of France is interesting in this respect. In the early $80 \mathrm{~s}$ of the 20 th century a decree was adopted in relation to the mandatory minimum for the area restoration after completion of works in the quarry. According to this decree, it was possible to reclaim quarries with the household and industrial waste in the cases where the quarries were located above the groundwater level. In the case of toxic wastes, its neutralization had to be applied prior to emplacement in the quarry.

The need for appropriate engineering and technical measures aimed at preventing the negative impact of the emplaced waste on the environment was also mentioned in the Letter of the Ministry of Natural Resources and Environment of Russia No.05-12-44/11342 dated June 02,2014 . This letter was dedicated to the possible use of production and consumption waste for the quarry recultivation. The document contains an indication that the waste emplacement without such measures can lead to the entry of harmful substances into the environment, its pollution and degradation. It also creates a risk of negative impact on human health.

The Federal Law No. 89-FZ allows two types of waste emplacement: it is the waste storage and warehousing in the specialized facilities performed for the purpose of disposal, neutralization, and burial; and burial that is understood as the waste isolation in the special 
storage facilities in order to prevent the entry of harmful substances into the environment. The waste emplacement in the form of landfilling is performed in relation to the waste that is not subject to further disposal.

The Federal Law No. 89-FZ requires the use of specially equipped facilities designed for waste emplacement and including the waste storage and burial facilities as the waste emplacement facilities.

Obviously, the solid household waste emplacement on the surface provides the same risks (or even greater risks, due to the fact that the open air medium and solar radiation are added to the factors contributing to the harmful waste effects, due to its unpredictable transformation over time), as in the case of emplacement in the quarry, if the appropriate security measures are not taken. However, at the same time, the one more factor is added that the usable area is covered by the waste.

Based on the study results, it can be concluded that, subject to the necessary measures, the use of waste for the quarry recultivation is a promising area for eliminating accumulated environmental damage. Therefore, this area needs further elaboration of legal regulation measures in relation to this type of activity.

The solution to the problem is currently seen in two planes: firstly, the prospective amendments to the applicable legislation in terms of permitting the quarry recultivation using any waste with the establishment for the natural resource user of the obligation at the legislative level to implement measures for prevention of the negative effects on the environment and human health. The second way is the abandoned quarry recultivation in two stages, the first of which includes the waste emplacement in the quarry on the conditions provided by the waste emplacement law, and the second stage includes the quarry recultivation using the methods permitted by applicable law.

\section{Acknowledgements}

The research was supported by the Ministry of Science and Higher Education in accordance with the state assignment for Ural State Mining University No. 0833-2020-0008 'Development and environmental and economic substantiation of the technology for reclamation of land disturbed by the mining and metallurgical complex based on reclamation materials and fertilizers of a new type'. We obtain the scientific results with the staff of Center for the collective use by using funds of the Center for the collective use of scientific equipment of the Federal Scientific Center of biological systems and agricultural technologies of RAS as well (No Ross RU.0001.21 PF59, the Unified Russian Register of Centers for Collective Use - http://www.ckp-rf.ru/ckp/77384).

\section{References}

1. K. L. Chertes, D.E. Bykov, Municipal solid waste, 8, 18-20 (2006)

2. G. E. Kudinova, Bulletin of the Samara Scientific Center of the Russian Academy of Sciences, 16(1), 306-312 (2014)

3. D. Alborov, S.A. Bekuzarova, R.V. Osikina, G.P. Khubaeva, D.G. Kachmazov, G.V. Lushchenko, I. Datieva, M. Dzampaeva, BIO Web of Conf., 17, 00260 (2020) https://doi.org/10.1051/bioconf/20201700260

4. V.L. Yakovlev, G.M. Chaikina, Mining Sciences at the Turn of the 21st Century: Proceedings of the International conference, 1997, Yekaterinburg, 482-487 (1998)

5. K. Chertes, O. Tupitsyna, V. Pystin, A. Savelyev, E. Martynenko, MATEC Web of Conferences, 86, 06003 (2016) https://doi.org/10.1051/matecconf/20168606003

6. M. Berezyuk, A. Rumyantseva, A. Lapina, E3S Web of Conferences, 6, 01006 (2016) 
7. Environmental protection in Russia. Statistical compilation, 125 (Moscow, 2018)

8. K. M. Akpambetova, Actual problems of human health and human environment formation: Proceedings of the International Scientific Conference, dedicated to the 30th anniversary of the Buketov Karaganda State University and the Year of Health, 23-27 (Karaganda: Publishing house of Karaganda State University, 2002)

9. L.A. Tikhomirova, Land Reclamation (2018)

10. Biological reclamation and monitoring of lands disturbed by industry, 282 (Yekaterinburg, 2015)

11. Equip. mec. Carrieres et mater., 210, 70-74 (1983)

12. O. Olson, Skillings Mining Rev., 10, 77-88 (1982)

13. A. Cancelli, V. Francani, Bull. Int. Assoc. Eng. Geol., 29, 237-240 (1984)

14. K. Werner, Sicherh., Bergbau, Energiewirt., Geol., Met. 2, 27-28 (1988)

15. A.S. Schipachev, S.V. Kovshov, V.P. Kovshov, Mining Information and Analytical Bulletin, 3, 102-108 (2014) 